\title{
Pengaruh Firm Size dan Growth Opportunity Terhadap Return on Assets dan Dividend Payout Ratio
}

\author{
Ade Febriani \\ Maya Sari \\ Program Studi Magister Manajemen, Universitas Muhammadiyah Sumatera Utara Medan, Indonesia \\ Jl. Denai No. 217, Tegal Sari Mandala II, Medan Denai, Kota Medan, Sumatera Utara 20371 \\ Email: mayasari@umsu.ac.id
}

\begin{abstract}
Abstrak. Tujuan penelitian ini adalah untuk mengetahui pengaruh langsung Firm Size dan Growth Opportunity terhadap Return On Assets dan pengaruh tidak langsung Firm Size, Growth Opportunity dan Return On Assets terhadap Dividend Payout Ratio pada perusahaan sub sektor otomotif yang terdaftar di Bursa Efek Indonesia Tahun 2013-2017.Pendekatan yang digunakan dalam penelitian ini adalah pendekatan asosiatif dimana diperoleh sample sebanyak 10 perusahaan dengan populasi 13 pada perusahaan Sub Sektor Otomotif yang sesuai dengan kriteria yang ditetapkan oleh penulis berdasarkan pengamatan yang dilakukan selama 5 tahun terakhir yaitu 2013-2017. Teknik pengumpulan data dalam penelitian ini menggunakan uji asumsi klasik dan path analisis,. Dalam penelitian ini pengolahan data digunakan dengan program SPSS (Statistic Package for the Social Sciens) versi 24.0 for windows. Hasil penelitian ini membuktikan bahwa secara langsung Firm Size berpengaruh negatif dan signifikan terhadap Return On Assets, Growth Opportunity tidak berpengaruh terhadap Return On Assets, Firm Size berpengaruh positif dan signifikan terhadap Dividend Payout Ratio, Growth Opportunity tidak berpengaruh terhadap Dividend Payout Ratio, Return On Assets tidak berpengaruh terhadap Dividend Payout Ratio, Firm Size berpengaruh langsung terhadap Dividend Payout Ratio tanpa dimediasi oleh Return On Assets, Growth Opportunity tidak berpengaruh langsung terhadap Dividend Payout Ratio tetapi harus dimediasi oleh Return On Assets, pada perusahaan sub sektor otomotif yang terdaftar di Bursa Efek Indonesia.
\end{abstract}

Kata kunci: Firm Size, Growth Opportunity, Return on Assets, Dividend Payout Ratio

Abstract. The aim of this study was to determine the direct effect of Firm Size and Growth Opportunity on Return On Assets and the indirect effect of Firm Size, Growth Opportunity and Return On Assets on Dividend Payout Ratio in automotive sub-sector companies listed on the Indonesia Stock Exchange 2013-2017.The approach used in this study is an associative approach where a sample of 10 companies is obtained with a population of 13 in the Automotive Sub-Sector companies that are in accordance with the criteria set by the author based on observations made over the last 5 years, 2013-2017.Data collection techniques in this study used the classic assumption test and path analysis. In this study data processing is used with the SPSS program (Package Statistics for Social Scenario) version 24.0 for Windows.The results of this study prove that Firm Size directly has a negative and significant effect on Return On Asset, Growth Opportunity has no effect on Return On Assets, Firm Size has a positive and significant effect on the Dividend Payout Ratio, Growth Opportunity has no effect on Dividend Payout Ratio, Return On Asset no effect on Dividend Payout Ratio, Firm Size has a direct effect on Dividend Payout Ratio without being mediated by Return On Asset, Growth Opportunity does not directly influence the Dividend Payout Ratio but must be mediated by Return On Asset, in automotive sub-sector companies listed on the Indonesia Stock Exchange

Keywords : Firm Size, Growth Opportunity, Return on Assets, Dividend Payout Ratio 


\section{PENDAHULUAN}

Bursa Efek Indonesia (BEI) atau Indonesian Stock Exchange (IDX) merupakan pasar modal yang ada di Indonesia. Bursa Efek Indonesia memiliki peranan penting sebagai sarana bagi masyarakat untuk berinvestasi, yang merupakan salah satu alternatif penanaman modal. Bagi perusahaan, BEI membantu perusahaan untuk mendapatkan tambahan modal dengan cara go public yaitu kegiatan penawaran saham atau efek lainnya yang dilakukan oleh emiten (perusahaan yang go public) kepada masyarakat berdasarkan tata cara yang diatur oleh UU Pasar Modal dan Peraturan Pelaksanaannya (Basir \& Fakhruddin, 2005).

Persaingan perkembangan dunia usaha pada saat ini semakin kritis dan tajam baik di sektor industri maupun jasa. Hal ini menyebabkan setiap perusahaan berupaya untuk dapat mempertahankan usahanya serta dapat menciptakan persaingan yang semakin kompetitif antar perusahaan satu dengan yang lainnya (Arseto \& Jufrizen, 2018).

Sehingga Pertumbuhan perusahaan di Indonesia secara kualitas maupun kuantitas cukup tinggi bila dilihat perkembangannya. Adanya perusahaan yang telah menjadi perusahaan publik dimana saham-sahamnya yang dahulu hanya dapat dimiliki oleh pemegang saham tertentu saja. Indonesia sebagai salah satu Negara yang berkembang dengan memiliki ciri-ciri adanya pembangunan di segala bidang. Salah satu kebijakan pemerintah Indonesia dalam mendukung pembangunan adalah di bidang perekonomian dunia usaha.

Dalam menghadapi persaingan tersebut, perusahaan dituntut untuk mempunyai keunggulan bersaing baik dalam hal produk, sumber daya manusia, maupun teknologi. Upaya yang dilakukan oleh perusahaan, antara lain menyesuaikan diri terhadap perubahan-perubahan yang terjadi di dalam maupun di luar perusahaan agar setiap sumber daya yang dimiliki perusahaan dapat digunakan secara efektif dan efisien. Namun, untuk memiliki keunggulan bersaing perusahaan membutuhkan dana yang semakin besar. Perusahaan mengatasi ketersediaan dana yang ada, perusahaan harus teliti dalam mencari sumber dana yang digunakan untuk membiayai investasi yang akan dilakukan oleh perusahaan.

Al-Saidi \& Al-Shammari, (2014) mengungkapkan bahwa dalam menjalankan perusahaan, biasanya pemilik melimpahkan pada pihak lain, yaitu manajer. Salah satu keputusan penting yang dihadapi manajer keuangan dalam kaitannya dengan kelangsungan kegiatan operasi perusahaan adalah keputusan pendanaan. Keputusan pendanaan yaitu suatu keputusan keuangan yang berkaitan dengan komposisi hutang, saham preferen dan saham biasa yang harus digunakan oleh perusahaan.

Hasnawati, (2005) mengungkapkan bahwa keputusan investasi dan kebijakan dividen berpengaruh positif terhadap nilai perusahaan. Kebijakan dividen secara langsung mempengaruhi nilai perusahaan dan secara tidak langsung mempengaruhi alokasi retained earnings terkait keputusan investasi.

Dalam kebijakan dividen, ada dua tipe keputusan yang harus diambil di akhir tahun oleh perusahaan terkait laba yang diperoleh secara kumulatif, apakah akan dibagian sebagai dividen, atau ditahan guna pembiayaan investasi. Perusahaan harus memberikan keputusan yang terbaik guna pemaksimalan kekayaan dari pemegang saham. Jika perusahaan tidak melihat adanya kesempatan investasi yang menguntungkan, maka sebaiknya dividen dibagikan ke pemegang saham. Namun perusahaan tidak harus mempertahankan jumlah dividen yang dibayarkan ke pemegang saham disetiap periode. Karena dalam jangka panjang, total laba ditahan, dan tambahan nilai sekuritas serta ekuitas akan secara tidak langsung meningkatkan nilai perusahaan yang bisa membuka peluang investasi yang lebih menguntungkan.

Para pemegang saham pasti ingin mendapatkan feedback yang besar terkait dengan investasi yang mereka berikan ke perusahaan. Oleh karena itu pihak manajemen harus pintar dalam penentuan alokasi dividen dan retained earnings perusahaan pada setiap periode. 
Besarnya alokasi laba yang digunakan untuk dividen, akan menjadi perhatian bagi para investor karena tidak dapat dipungkiri, investor akan lebih menyukai nominal dividen yang besar, sedangkan hal tersebut tidak dikehendaki oleh manajemen yang lebih memilih untuk menahan laba perusahaan.

Perbedaan persentase dividen tersebut terlihat pada data dividend payout ratio perusahaan otomotif pada periode 2013 hingga 2017. Hal itu dapat disebabkan oleh banyak hal, seperti contohnya keadaan ekonomi negara, lalu adanya kebijakan dari perusahaan terkait penggunaan laba perusahaan, berapa besar yang akan dialokasikan untuk dividen, dan dialokasikan guna retained earnings untuk dana modal perusahaan dalam melakukan ekspansi. Serta masih banyak lagi hal - hal lain yang bisa sangat berpengaruh terhadap kebijakan dividen yang diambil perusahaan dalam tiap periode. Adanya hal tersebut, akan sangat berpengaruh pada keputusan besarnya dividend payout ratio perusahaan yang dianggap manajemen paling maksimal pada tiap periode, yang tidak mengalami ketimpangan kepentingan antara berapa besarnya dividen.

\section{LANDASAN TEORI \\ Dividend Payout Ratio}

Hery, (2018) menyatakan Dividen Payout Ratio (DPR) merupakan rasio yang menunjukan hasil perbandingan antara dividen tunai perlembar saham dengan laba perlembar saham. Rasio ini menggambarkan jumlah laba dari setiap lembar saham yang dialokasikan dalam bentuk dividen. Sedangkan (Harmono, 2015) menyatakan bahwa Dividen Payout Ratio merupakan rasio pembayaran dividen, ikut menentukan besarnya jumlah laba yang ditahan perusahaan harus dievaluasi dalam kerangka tujuan pemaksimalan kekayaan para pemegang saham. Horne \& Wachowicz, (2009) menyatakan Dividen Payout Ratio merupakan rasio pembayaran dividen yang menentukan jumlah saldo laba dalam perusahaan sebagai sumber pendanaan. Akan tetapi, dengan menahan laba saat ini dalam jumlah yang lebih besar dalam perusahaan juga berarti lebih sedikit uang yang akan tersedia bagi pembayaran dividen saat ini.

Dari teori diatas dapat disimpulkan bahwa Dividen Payout Ratio adalah perbandingan antara dividen yang dibayarkan dengan laba bersih yang didapatkan, semakin tinggi Dividen Payout Ratio akan menguntungkan pihak investor tetapi pada pihak perusahaan akan memperlemah internal financial karena memperkecil laba ditahan. Tetapi sebaliknya Dividen Payout Ratio semakin kecil akan merugikan pemegang saham (investor) internal financial perusahaan semakin kuat (Rambe et al., 2015).

Dalam pembagian divide ada beberapa faktor penting harus dipertimbangkan oleh direksi perusahaan tentang apakah dividen harus atau tidak harus dibagikan, serta bentuk dan jumlahnya. Menurut (Gumanti, 2013) mengidentifikasi setidaknya ada 11 faktor yang dapat mempengaruhi kebijakan dividen perusahaan antara lain: 1) undang-undang 2) posisi likuiditas 3) kebutuhan untuk pelunasan utang 4) batasan-batasan dalam perjanjian hutang 5) potensi ekspansi aktiva 6) perolehan laba 7) stabilitas laba 8) peluang penerbitan saham di pasar modal 9) kendali kepemilikan 10) posisi pemegang saham, dan 11) kesalahan akumulasi pajak atas laba. Sedangkan (Sartono, 2016) menyatakan faktor- faktor yang mempengaruhi kebijakan dividen antara lain: 1) kebutuhan dana perusahaan 2) likuiditas 3) kemampuan meminjam 4) keadaan pemegang saham 5) stabilitas dividen.

Pembagian dividen yang dilakukan perusahaan memiliki tujuan, menurut (Andinata, 2010) menyatakan tujuan dan manfaat dari pembagian dividen adalah yaitu : 1) untuk memaksimumkan kemakmuran bagi para pemegang saham, karena tingginya dividen yang dibayarkan akan mempengaruhi harga saham 2) untuk menunjukan likuiditas perusahaan. dengan dibayarkannya dividen, diharapkan kinerja perusahaan dimata investor bagus dan dapat 
diakui bahwa perusahaan mampu menghadapi gejolak ekonomi dan mampu memberikan hasil kepada investor 3) sebagian investor memandang bahwa risiko dividen adalah lebih rendah dibanding risiko capital gain. 4) untuk memenuhi kebutuhan para pemegang saham akan pendapatan tetap yang digunakan untuk keperluan konsumsi 5) dividen dapat digunakan sebagai alat komunikasi antara manajer dan pemegang saham.

Dividend payout ratio banyak digunakan dalam penilaian sebagai cara pengestimasian dividen untuk periode yang akan datang. Indikator Dividen Payout Ratio menurut (Murhadi, 2013) yaitu :

$$
\text { Dividend Payout Ratio }=\frac{\text { Divident Per Saher }}{\text { Earning Per Share }} \times 100 \%
$$

Sumber : (Hani, 2015)

\section{Return On Assets}

Return on Asset merupakan salah satu rasio profitabilitas. Dalam analisis laporan keuangan, rasio ini paling sering disoroti, karena mampu menunjukkan keberhasilan perusahaan menghasilkan keuntungan. ROA mampu mengukur kemampuan perusahaan dalam manghasilkan keuntungan juga memberikan ukuran tingkat efektivitas manajemen suatu perusahaan.

Menurut (Brigham \& Houston, 2011) Return On Assets (ROA) adalah rasio laba bersih terhadap total aset mengukur pengembalian atas total aset setelah bunga dan pajak. Menurut (Sartono, 2016) Return On Asset (ROA) menujukkan kemampuan perusahaan menghasilkan laba dari aktiva yang dipergunakan". Dan Rahardjo (2010,hal.103) berpendapat bahwa, "Return On Total Assets digunakan untuk menunjukkan kemampuan perusahaan dengan seluruh modal yang ada didalamnya untuk menghasilkan keuntungan". Dari beberapa teori dapat disimpulkan bahwa Return On Assets adalah rasio yang digunakan untuk menghasilkan laba dari total aktiva perusahaan.

Banyak factor yang mempengaruhi Return On Assets, diantaranya Menurut (Sartono, 2016) tinggi rendahnya Return On Assets ditentukan oleh dua faktor yaitu: 1)Profit Margin, yaitu perbandingan antara "net operating income" dengan "net sales", perbandingan dimana dinyatakan dalam persentase 2) Turnover of operating assets (tingkat perputaran aktiva usaha), yaitu kecepatan berputarnya operating assets dalam suatu periode tertentu dan menurut (Munawir, 2018) Return On Assets dipengaruhi oleh dua faktor, yaitu : 1) Turnover dari operating asets (tingkat perputaran aktiva yang digunakan untuk operasi) 2) Profut Margin,yaitu besarnya keuntungan operasi yang dinyatakan dalam presentase dan jumlah penjualan bersih. Profit margin ini mengukur tingkat keuntungan yang dapat dicapai oleh perusahaan dihubungkan dengan penjualannya. Rasio profitabilitas juga memiliki tujuan dan manfaat, tidak hanya bagi pemilik usaha atau manajemen saja, tetapi juga bagi pihak di luar perusahaan, terutama pihak-pihak yang memiliki hubungan atau kepentingan dengan perusahaan.

Menurut (Munawir, 2018) menyatakan kegunaan dari Return On Asset dikemukakan sebagai berikut : 1) Sebagai salah satu kegunaanya adalah sifatnya yang menyeluruh apabila perusahaan sudah menjalankan praktek akuntansi yang baik maka manajemen dengan menggunakan dengan menggunakan Return On Assets dapat mengukur efisiensi penggunaan modal yang bekerja, efisiensi produksi dan efisiensi penjualan 2) Apabila perusahaan dapat mempunyai data industri sehingga dapat diproleh rasio industri, Maka dengan Return On Assets ini dapat dibandingkan efisiensi penggunaan modal pada perusahaannya dengan perusahaan lain yang sejenis, sehingga dapat diketahui apakah perusahaan berada dibawah, sama atau di atas rata-ratanya. Dengan demikian akan dapat diketahui kelemahan dan apa kuat pada 
perushaan tersebut dibandingkan perusahaan lain 3) Return On Asset (ROA) dapat juga digunakan untuk mengukur efisiensi tindakan yang dilakukan oleh bagian, yaitu dengan mengalokasikan semua biaya dan modal kedalam bagian yang bersangkutan. Arti pentingnya mengukur rate of return pada tingkat bagian. Untuk membandingkan efisiensi suatu bagian ke bagian lain di dalam perusahaan 4) Return On Assets juga dapat digunakan untuk mengukur profitabilitas dari masing-masing yang dihasilkan perusahaan dengan menggunakan produk cosh system yang baik 5) Return On Asset selain berguna untuk keperluan kontrol, juga berguna untuk keperluan perencanaan misalnya digunakan sebagai dasar untuk pengembalian keputusan kalau perusahaan akan mengadakan ekspansi. (Kasmir, 2012) tujuan penggunaan rasio profitabilitas bagi perusahaan, maupun bagi pihak luar perusahaan, yaitu : 1) Untuk mengukur atau menghitung laba yang diperoleh perusahaan dalam satu periode tertentu 2) Untuk menilai posisi laba perusahaan tahun sebelumnya dengan tahun sekarang 3) Untuk menilai perkembangan laba dari waktu ke waktu 4) Untuk menilai besarnya laba bersih sesudah pajak dengan modal sendiri 5) Untuk mengukur produktivitas seluruh dana perusahaan yang digunakan baik modal pinjaman maupun modal sendiri 6) Untuk mengukur produktivitas seluruh dana perusahaan yang digunakan baik modal pinjaman maupun modal sendiri.

Profitabilitas dapat dinilai dengan berbagai cara, salah satunya adalah menggunakan rasio. Rasio yang lazim digunakan dalam mengukur profitabilitas adalah Return On Assets (ROA).

$$
\text { Return On Asset }=\frac{\text { Laba setelah pajak }}{\text { Total Aktiva }}
$$

Sumber : (Sartono, 2016)

$$
\mathrm{ROA}=\frac{\text { Laba Bersih Setelah Pajak }}{\text { Total Assets }}
$$

Sumber : (Harmono, 2015)

\section{Ukuran Perusahaan (Firm Size)}

Ukuran perusahaan menggambarkan besar kecilnya suatu perusahaan dimana perusahaan yang besar akan lebih mudah mendapatkan pinjaman dari luar baik dalam bentuk utang maupun modal saham karena biasanya perusahaan yang besar disertai dengan reputasi yang cukup baik dimata masyarakat. Menurut (Sartono, 2016) mengemukakan bahwa, "perusahaan besar akan lebih mudah memperoleh modal di pasar modal dibanding dengan perusahaan kecil". Menurut (Palupi, 2011) menyatakan bahwa, "ukuran mencerminkan besar keculnya perusahaan. Perusahaan dengan ukuran lebih besar akan membutuhkan dana yang lebih besar pula dibandingkan perusahaan kecil. (Brigham \& Houston, 2011) ukuran perusahaan adalah sebagai berikut: "Ukuran perusahaan merupakan ukuran besar kecilnya sebuah perusahaan yang ditunjukan atau dinilai oleh total asset, total penjualan, jumlah laba, beban pajak dan lain-lain".

Berdasarkan beberapa referensi tersebut dapat dsimpulkan bahwa ukuran perusahaan yaitu besar kecilnya suatu perusahaan.Dengan demikian, ukuran perusahaan merupakan ukuran atau besarnya aset yang dimiliki perusahaan.

Ukuran perusahaan menunjukkan seberapa besar perusahaan dilihat dari total aset yng dimiliki. Menurut (Brigham \& Houston, 2011) ukuran perusahaan dipengaruhi oleh beberapa faktor sebagai berikut : 1) tingkat kemudahan perusahaan memperoleh dana dari pasar modal 2) kekuatan tawar menawar dalam kontrak keuangan 3) pengaruh skala dalam biaya dan return. 
Sedangkan menurut (Torang, 2012) ukuran perusahaan sangat berpengaruh pada tiga faktor utama, yaitu: 1) besarnya total aktiva 2) besarnya hasil penjualan 3) besarnya kapitalisasi pasar.

Ukuran perusahaan dapat dinyatakan dalam total aktiva, penjualan dan kapitalisasi pasar, semakin besar total aktiva, penjualan dan kapitalisasi pasarnya maka semakin besar pula ukuran perusahaan tersebut. Ketiga variabel tersebut dapat digunakan untuk menentukan ukuran perusahaan. Menurut Joni dan Lina (2010,hal.91) ukuran perusahaan diproksikan dengan menggunakan natural logaritma $(\ln )$ dari total aktiva.

Ukuran perusahaan $=$ Ln Total Aktiva

Sedangkan menurut (Pasadena, 2013) yaitu log natural dari total aset.

Ukuran Perusahaan $=$ Ln $($ Total Aset $)$

\section{Pertumbuhan Perusahaan}

Menurut (Machfoedz, 2009), pertumbuhan (Growth) adalah seberapa jauh perusahaan menempatkan diri dalam sistem ekonomi secara keseluruhan atau sistem ekonomi untuk industri yang sama. Pertumbuhan perusahaan sangat diharapkan oleh pihak internal maupun eksternal perusahaan, karena pertumbuhan yang baik memberi tanda bagi perkembangan perusahaan. Menurut (Susanto, 1997) pada umumnya perusahaan yang tumbuh dengan cepat memperoleh hasil positif dalam artian pemantapan posisi dipersaingan, menikmati penjualan yang meningkat secara signifikan dan diiringi adanya peningkatan pangsa pasar. Perusahaan yang tumbuh juga akan mendapat keuntungan lain yaitu citra positif. (Atmaja, 2008) menyatakan bahwa:"perusahaan dengan tingkat pertumbuhan yang tinggi pada umumnya tergantung pada modal dari luar perusahaan. Pada perusahaan dengan tingkat pertumbuhan yang rendah kebutuhan baru relative kecil sehingga dapat dipenuhi dari laba ditahan. (Prasetyo, 2011) menyatakan pertumbuhan Aset: "Pertumbuhan perusahaan selalu identik dengan aset perusahaan (baik asset fisik seperti tanah, bangunan, gedung sertaaset keuangan seperti kas, piutang dan lain sebgaianya). Paradaigma asset sebagai indikator pertumbuhan perusahaan merupakan hal yang lazim digunakan. Nilai total asset dalam neraca menentukan kekayaan perusahaan".

Dari beberapa teori diatas dapat diketahui pertumbuhan perusahaan sangat diharapkan oleh banyak pihak baik internal maupun eksternal, karena pertumbuhan yang baik memberi tanda bagi perkembangan perusahaan. Pertumbuhan suatu perusahaan merupakan tanda perusahaan memiliki aspek yang menguntungkan, karena dianggap mampu menghasilkan keuntungan yang lebih baik dari waktu ke waktu.

Pertumbuhan perusahaan pada dasarnya dipengaruhi oleh beberapa faktor, yaitu faktor eksternal, internal, dan pengaruh iklim industri lokal. Menurut (Prasetyo, 2011), terdapat dua bentuk pertumbuhan perusahaan: 1) pertumbuhan dari luar (external growth) yang menyangkut faktor-faktor dari luar yang tidak dapat dikendalikan oleh perusahaan, seperti harga, keadaan politik, karakteristik masyarakat, dan sebagainya. semakin baik kondisi dari luar, maka pertumbuhan perusahaan juga akan semakin meningkat 2) pertumbuhan dari dalam (internal growth) yang menyangkut produktivitas perusahaan. semakin baik produktivitas perusahaan, maka pertumbuhan perusahaan tersebut juga semakin semakin meningkat.

Menurut (Warsono, 2003) faktor -faktor yang mempengaruhi pertumbuhan perusahaan meliputi: 1) customer (pelanggan atau konsumen) 2) relationships (hubungan relasi) 3) products and services (produk dan jasa) 4) resources (sumber daya) 5) procedurs (prosedur) 6) yourself (diri sendiri) 7) stakeholders (investor). Menurut (Halim, 2016) tingkat pertumbuhan aktiva dihitung dengan proporsi perubahan aktiva dari suatu periode tahunan ke periode tahunan berikutnya. Bila persentase perubahan total aktiva dari suatu periode ke periode 
berikutnya tinggi, maka semakin besar risiko yang akan ditanggung oleh pemegang saham. Rasio ini dapat dihitung dengan rumus:

$$
\text { Growth }=\frac{\text { Total Asset }_{t}-\text { Total Asset }_{t-1}}{\text { Total Asset }_{t-1}}
$$

\section{METODE PENELITIAN}

Pendekatan dalam penelitian ini adalah menggunakan pendekatan Asosiatif. Teknik pengumpulan data yang digunakan adalah data dokumenter. Populasi pada penelitian ini adalah13 perusahaan sub sektor otomotif yang terdaftar di Bursa Efek Indonesia tahun 2013-2017. Jumlah sampel yang digunakan pada penelitian ini berjumlah 10 perusahaan yang mempublis laporan keuangan tahun 2013-2017. Jenis data yang digunakan data yang bersifat kuantitatif, yaitu berbentuk angka dengan menggunakan instrumen formal, standar dan terukur.Pengolahan data menggunakan perangkat lunak SPSS versi 24, dengan pengujian asumsi klasik, dan teknik analisi data menggunakan analisis jalur (Path Analysis).

\section{HASIL DAN PEMBAHASAN PENELITIAN Uji Asumsi Klasik \\ Uji Normalitas}

Uji normalitas bertujuan untuk menguji apakah dalam metode regresi, variabel terikat dan variabel bebas keduanya mempunyai distribusi normal atau tidak. Model regresi yang baik adalah data yang berdistribusi normal atau mendekati normal. Berikut adalah hasil pengujian normalitas dapat dilihat dari grafik probability plot, hasil penelitian data yang telah diolah dengan pengujian SPSS versi 24.0 adalah sebagai berikut:

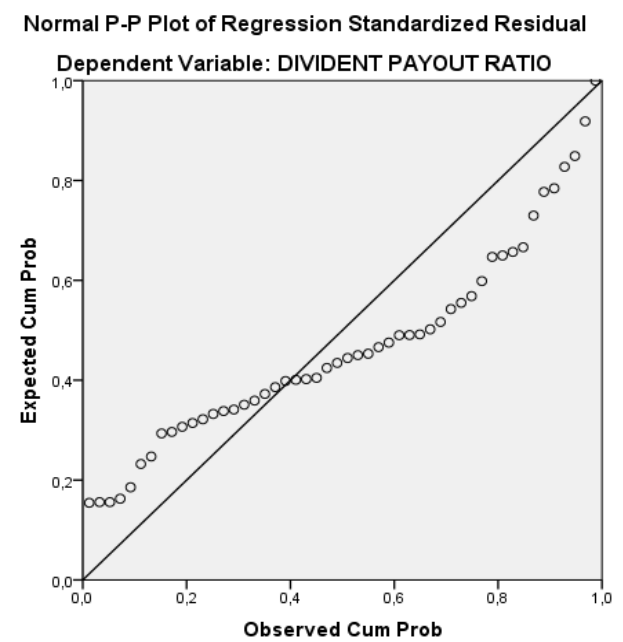

\section{Gambar 1. Hasil Pengujian Normalitas}

Pada gambar diatas diketahui hasil dari pengujian normalitas bahwa data menunjukkan penyebaran titik-titik data cenderung mendekati garis diagonal. Sehingga dapat disimpulkan bahwa data yang diolah merupakan data yang berdistribusi normal dan uji normalitas terpenuhi.

\section{Uji Multikolinieritas}

Multikolinieritas digunakan untuk menguji apakah pada model regresi ditemukan adanya korelasi yang kuat antar variabel independen (Juliandi, Irfan, \& Manurung, 2015). Cara 
yang digunakan untuk menilainya adalah dengan melihat nilai faktor inflasi varians (Variance Inflasi Factor/VIF), yang tidak melebihi 4 atau 5.

\section{Tabel 1. Hasil Pengujian Multikolinearitas}

\begin{tabular}{|c|c|c|c|}
\hline \multirow[b]{2}{*}{ Model } & & \multicolumn{2}{|c|}{ Collinearity Statistics } \\
\hline & & Tolerance & VIF \\
\hline \multirow[t]{4}{*}{1} & (Constant) & & \\
\hline & firm size &, 725 & 1,379 \\
\hline & growth opportunity &, 977 & 1,024 \\
\hline & return on asset &, 739 & 1,353 \\
\hline
\end{tabular}

Dari tabel diatas menunjukkan nilai VIF masing-masing variabel yaitu variabel firm size (X1) sebesar 1.379, growth opportunity (X2) sebesar 1,024 dan return on assets (Y1) sebesar 1,353 maka dapat diketahui bahwa nilai VIF dalam batas toleransi yang telah ditentukan tidak melebihi batas korelasi yang telah ditentukan yaitu tidak lebih besar dari 4 atau 5. Maka model ini tidak terjadi masalah multikolinearitas.

\section{Uji Heteroskedastisitas}

Pengujian ini memiliki tujuan untuk mengetahui apakah dalam model regresi terjadi ketidaksamaan varian dari residual suatu pengamatan ke pengamatan lainnya. Jika varian dari residual satu pengamatan ke pengamatan lain tetap, maka disebut homokedassitas dapat diketahui dengan melalui grafik scatterplot antar nilai prediksi varabel independen dengan nilai residualnya.

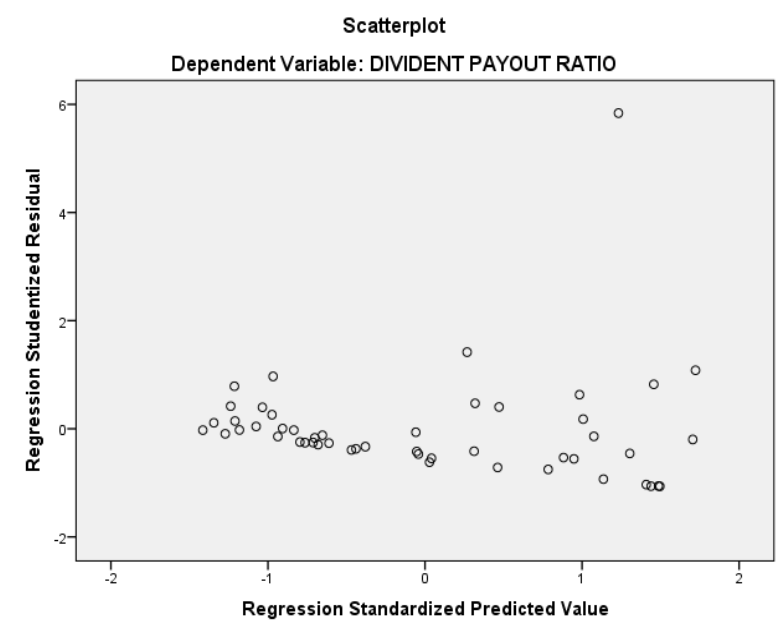

Gambar 1. Hasil Pengujian Heteroskedasitas

Dari gambar grafik scatterplot diatas dapat diketahui bahwa tidak terjadi heteroskedastisitas pada model regresi ini. Sebab tidak ada pola yang jelas serta titik-titik menyebar diatas dan dibawah angka 0 pada sumbu $\mathrm{Y}$, maka kesimpulannya tidak terjadi heteroskedasitas. 
DOI: https://doi.org/10.30596/maneggio.v2i2.3775

\section{Analisis Data}

Koefisien regresi dalam model persamaan I

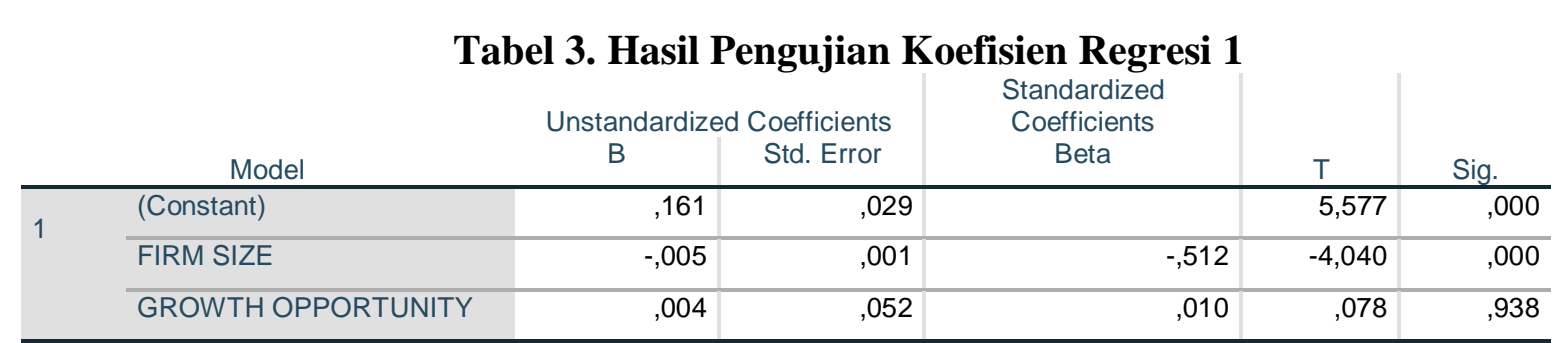

a. Dependent Variable: RETURN ON ASSET

Dari tabel coefficient diatas (pada kolom Standardize Coefficients) dapat dilihat nilai-nilai koefisien regresinya adalah sebagai berikut:

a) Koefisien firm size (X1) adalah p1 $=-0,512$

b) Koefisien growth opportunity (X2) adalah p2 $=0,010$

Tabel 4. Hasil Pengujian Adjusted R Square 1

\begin{tabular}{cc|c|c|c} 
& & \multicolumn{3}{c}{ Model Summary } \\
Model & $\mathrm{R}$ & $\mathrm{R}$ Square & $\begin{array}{c}\text { Adjusted R } \\
\text { Square }\end{array}$ & $\begin{array}{c}\text { Std. Error of the } \\
\text { Estimate }\end{array}$ \\
\hline 1 &, $511^{\mathrm{a}}$ &, 261 &, 230 &, 05715 \\
\hline
\end{tabular}

a. Predictors: (Constant), GROWTH OPPORTUNITY, FIRM SIZE

Sedangkan dari model summary di atas nilai Adjusted-R adalah 0,230. Nilai ini dapat digunakan untuk menentukan koefisien jalur dengan residualnya, yakni: $P \varepsilon_{1}=\sqrt{ }\left(1-R^{2}{ }_{1}\right)=$ $\sqrt{(1-0,230)}=0,877$.

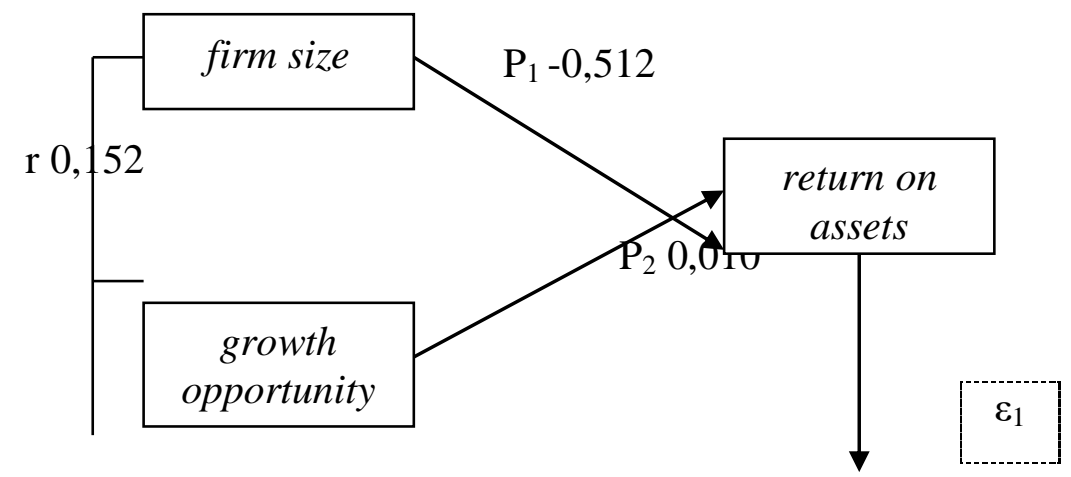

Gambar 3. Diagram Jalur Persamaan I

\section{Koefisien regresi dalam model persamaan II}

Tabel 5. Hasil Pengujian Koefisien Regresi 2

\begin{tabular}{|c|c|c|c|c|c|c|}
\hline \multirow{2}{*}{\multicolumn{2}{|c|}{ Model }} & \multicolumn{2}{|c|}{$\begin{array}{c}\text { Unstandardized } \\
\text { Coefficients }\end{array}$} & \multirow{2}{*}{$\begin{array}{c}\text { Standardized } \\
\text { Coefficients } \\
\text { Beta }\end{array}$} & \multirow[b]{2}{*}{$\mathrm{T}$} & \multirow[b]{2}{*}{ Sig. } \\
\hline & & $\mathrm{B}$ & Std. Error & & & \\
\hline \multirow[t]{4}{*}{$\overline{1}$} & (Constant) &,- 316 & ,249 & & $-1,268$ & ,211 \\
\hline & FIRM SIZE & ,024 & 011 & ,369 & 2,249 & ,029 \\
\hline & $\begin{array}{l}\text { GROWTH } \\
\text { OPPORTUNITY }\end{array}$ &,- 230 & ,347 &,- 093 &,- 662 &, 512 \\
\hline & RETURN ON ASSETS & 1,359 & ,975 & ,227 & 1,395 &, 170 \\
\hline
\end{tabular}

a. Dependent Variable: DIVIDENT PAYOUT 
Dari tabel coefficients diatas (pada kolom Standardize Coefficients) dapat dilihat nilai-nilai koefisien regresinya adalah sebagai berikut:

a) Koefisien firm size (X1) adalah p3 =0,369

b) Koefisien growth opportunity (X2) adalah p4 $=-0,093$

c) Koefisien return on assets (Y1) adalah p5 = -0,227

Tabel 5. Hasil Pengujian Adjusted R Square 2

\begin{tabular}{|c|c|c|c|c|}
\hline \multicolumn{5}{|c|}{ Model Summary } \\
\hline Model & $\mathrm{R}$ & R Square & $\begin{array}{l}\text { Adjusted R } \\
\text { Square }\end{array}$ & $\begin{array}{c}\text { Std. Error of the } \\
\text { Estimate }\end{array}$ \\
\hline 1 &, $321^{a}$ &, 103 &, 045 & ,38181 \\
\hline
\end{tabular}

Sedangkan dari model summary di atas nilai Adjusted-R adalah 0,045. Nilai ini dapat digunakan untuk menentukan koefisien jalur dengan residualnya, yakni: $P \varepsilon_{2}=\sqrt{ }\left(1-R_{2}^{2}\right)=$ $\sqrt{(1-0,045)}=0,977$.

Yakni: $\left.P \varepsilon_{2}=\sqrt{\left(1-R^{2}\right.}{ }_{2}\right)=\sqrt{ }(1-0,062)=0,977$.

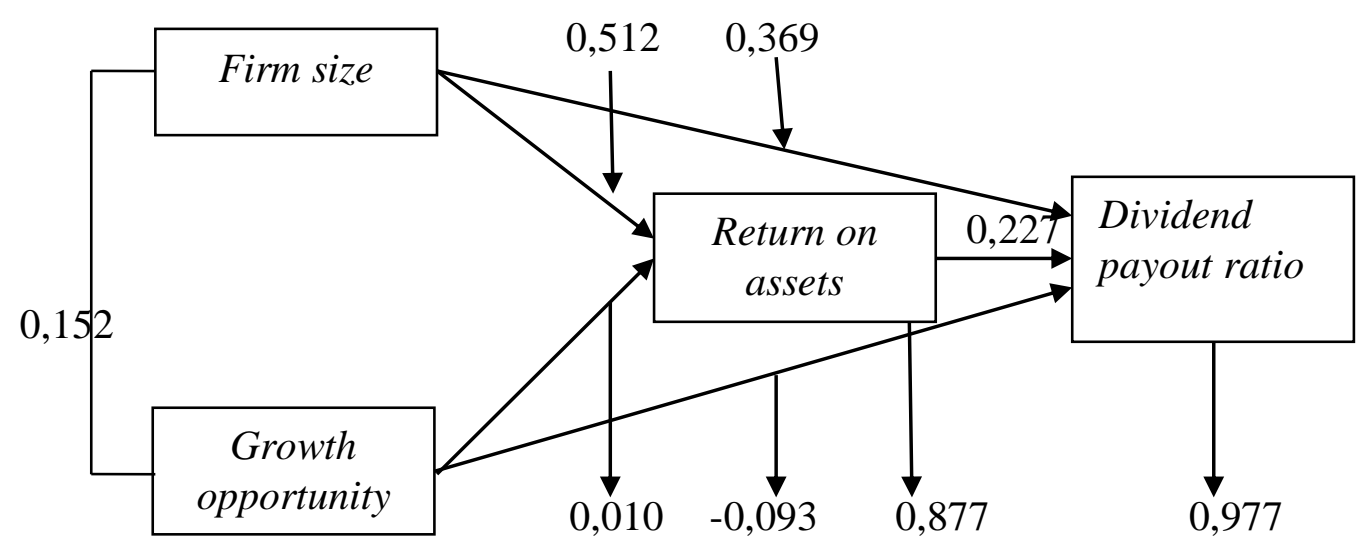

Gambar 5. Diagram Jalur Persamaan II

Dari gambar diatas dapat dapat disimpulkan bahwa pengaruh langsung dan tidak langsung variabel-variabel tersebut dalam analisis sebagai berikut: Analisis pengaruh firm size $\left(\mathrm{X}_{1}\right)$ terhadap return on assets $\left(\mathrm{Y}_{1}\right)$ adalah dengan nilai sig. $0,000<0,05$, maka $\mathrm{H} 0$ ditolak sehingga firm size berpengaruh signifikan terhadap return on assets. Analisis pengaruh growth opportunity $\left(\mathrm{X}_{2}\right)$ terhadap return on assets $(\mathrm{Y} 1)$ adalah dengan nilai sig.0,938>0,05, maka $\mathrm{H} 0$ diterima sehingga growth opportunity berpengaruh tidak signifikan terhadap return on assets. Analisis pengaruh firm size $\left(\mathrm{X}_{1}\right)$ terhadap dividend payout ratio $\left(\mathrm{Y}_{2}\right)$ adalah dengan nilai sig.0,029<0,05, maka $\mathrm{H} 0$ ditolak sehingga firm size berpengaruh signifikan terhadap dividend payout ratio. Analisis pengaruh growth opportunity $\left(\mathrm{X}_{2}\right)$ terhadap dividend payout ratio $\left(\mathrm{Y}_{2}\right)$ adalah dengan nilai sig.0,512 > 0,05, maka H0 diterima sehingga growth opportunity berpengaruh tidak signifikan terhadap dividend payout ratio. Analisis pengaruh langsung return on assets (Y1) terhadap dividend payout ratio $\left(\mathrm{Y}_{2}\right)$ adalah dengan nilai sig.0,170>0,05, maka $\mathrm{H} 0$ diterima sehingga return on assets berpengaruh tidak signifikan terhadap dividend payout ratio. Sedangkan analisis pengaruh tidak langsung $\mathrm{X}_{1}$ terhadap $\mathrm{Y}_{2}$ melalui $\mathrm{Y}_{1}$ yaitu dengan koefisien pengaruh langsung, tidak langsung dengan nilai koefisien pengaruh tidak 
langsung < pengaruh langsung (p1 x p5 < p3) yakni $-0,1162<0,369$, maka firm size $\left(\mathrm{X}_{1}\right)$ berpengaruh langsung terhadap dividend payout ratio (Y2) tidak harus melalui return on assets $\left(\mathrm{Y}_{1}\right)$. Hal ini terlihat bahwa return on assets $(\mathrm{Y} 1)$ tidak dapat memediasi tetapi pengaruh yang sebenarnya adalah langsung. Analisis pengaruh tidak langsung $X_{2}$ terhadap $Y_{2}$ melalui $Y_{1}$ yaitu dengan koefisien pengaruh langsung, tidak langsung dengan nilai koefisien pengaruh tidak langsung < pengaruh langsung (p2 x p5 < p4) yakni 0,0022>-0,093 maka growth opportunity $\left(\mathrm{X}_{2}\right)$ berpengaruh langsung terhadap dividend payout ratio $(\mathrm{Y} 2)$ tidak harus melalui return on assets $\left(\mathrm{Y}_{1}\right)$. Hal ini terlihat bahwa return on assets $\left(\mathrm{Y}_{1}\right)$ dapat memediasi tetapi pengaruh yang sebenarnya adalah tidak langsung.

\section{PEMBAHASAN}

\section{Pengaruh Firm Size terhadap Return On Assets}

Berdasarkan hasil penelitian yang diperoleh mengenai firm size terhadap Return On Assets pada Pada Perusahaan Otomotif yang terdaftar di BEI Tahun 2013-2017 menyatakan bahwa Firm Size berpengaruh negatif dan signifikan. Hal ini dapat dilihat dari nilai sig.0,000 lebih kecil dari nilai signifikan 0,05. Berdasarkan hasil yang telah diperoleh maka H0 ditolak.

Perusahaan yang mampu mengelola seluruh sumber daya yang dimiliki akan semakin baik dalam menghasilkan laba sehingga kinerja perusahaan terlihat sangat baik. Dengan efektifitas dan kinerja yang yang baik maka profit perusahaan akan meningkat. Dari hasil penelitian ada pengaruh negatif Firm Size terhadap profit yang artinya meningkatnya Firm Size diikuti oleh penurunan Return On Assets. Meningkatnya Firm Size menunjukkan bahwa perusahaan mampu dalam mengelola sumber daya yang dimiliki Firm Size yang besar semakin baik. Firm Size yang besar dapat meningkatkan skala yang baik bagi ekonomi. Perusahaan besar dan mapan akan cukup mudah untuk memasuki pasar modal, kemudahaan yang dimiliki perusahaan dengan pasar modal akan dapat meningkatkan kepercayaan investor. Hasil penelitian tersebut sesuai dengan penelitian yang dilakukan oleh (Riawan, 2019); (Kopong \& Nurzana, 2016) dan (Manoppo \& Arie, 2016) yang mengatakan bahwa ukuran perusahaan berpengaruh signifikan terhadap Return On Assets. Berdasarkan hasil penelitian yang dilakukan yang didukung oleh penelitian terdahulu mengenai pengaruh Firm Size terhadap Return On Assets maka dapat disimpulkan bahwa ada kesesuaian antara hasil penelitian dengan penelitian terdahulu yakni adanya pengaruh signifikan Firm Size terhadap Return On Assets.

\section{Pengaruh Growth Opportunity terhadap Return On Assets}

Berdasarkan hasil penelitian yang diperoleh mengenai Growth Opportunity terhadap Return On Assets pada Pada Perusahaan Otomotif yang terdaftar di BEI Tahun 2013-2017 menyatakan bahwa tidak berpengaruh signifikan. Hal ini dapat dilihat dari nilai sig.0,938 lebih besar dari nilai signifikan 0,05 . Berdasarkan hasil yang telah diperoleh maka H0 diterima. Besarnya growth opportunity sebuah perusahaan, akan berpengaruh pada jumlah dana yang dibutuhkan untuk investasi dll. Kurangnya kinerja Manajemen perusahaan dalam mengelola sumber daya baik itu eksternal maupun internal yang dapat mnghambat pertumbuhan perusahaan pada tiap periode. Dalam mengambil keputusan para investor akan sangat memperhatikan kinerja perusahaan. Hasil penelitian tersebut sesuai dengan penelitian yang dilakukan oleh (Husna, 2016) dan (Kopong \& Nurzana, 2016) yang mengatakan bahwa ukuran perusahaan berpengaruh signifikan terhadap Return On Assets. Berdasarkan hasil penelitian yang dilakukan yang didukung oleh penelitian terdahulu mengenai pengaruh Growth Opportunity terhadap Return On Assets maka dapat disimpulkan bahwa ada kesesuaian antara hasil penelitian dengan penelitian terdahulu yakni tidak ada pengaruh signifikan Growth Opportunity terhadap Return On Assets. 


\section{Pengaruh Firm Size terhadap Dividend Payout Ratio}

Berdasarkan hasil penelitian yang diperoleh mengenai Firm Size terhadap Dividend Payout Ratio pada Pada Perusahaan Otomotif yang terdaftar di BEI Tahun 2013-2017 menyatakan bahwa Firm Size berpengaruh positif dan signifikan. Hal ini dapat dilihat dari nilai sig.0,029 lebih kecil dari nilai signifikan 0,05. Berdasarkan hasil yang telah diperoleh maka H0 ditolak. Firm Size merupakan ukuran perusahaan, size menunjukkan dasar teori pada pengaruh dari ukuran (size ) terhadap Divident Payout Ratio sangat kuat. Perusahaan besar akan mampu mempertahankan kelangsungan hidupnya dan dapat mengakses kepasar modal dengan lebih mudahkan dibandingkan dengan perusahaan yang kecil. Oleh karena itu, perusahaan dengan ukuran yang lebh besar diperkirakan akan memiliki kemampuan menghasilkan earning yang lebih besar, sehingga akan mampu membayar dividen yang lebih tinggi kepada pemegang saham dibandingkan dengan perusahaan kecil, sehingga ukuran perusahaan dan pemegang saham dan pembayaran dividen memiliki hubungan positif.

Firm size memiliki pengaruh positif dan signifikan terhadap Dividend Payout Ratio (DPR). Artinya semakin besar firm size maka Dividend Payout Ratio (DPR) yang dibagikan semakin besar pula. Suatu perusahaan yang telah mapan memiliki akses yang mudah menuju pasar modal karena risiko yang dihadapi oleh perusahaan-perusahaan besar cukup tinggi. Banyaknya assets yang dimiliki perusahaan besar dapat menjadi jaminan untuk melakukan pembayaran dividen kepada investor. Hasil penelitian ini tidak sejalan dengan penelitian yang dilakukan oleh (Hanif \& Bustamam, 2017) yang menyatakan bahwa ukuran perusahaan tidak berpengaruh signifikan terhadap Dividend Payout Ratio. Berdasarkan hasil penelitian yang dilakukan (Sari, 2014) menyimpulkan adanya pengaruh signifikan Firm Size terhadap Dividend Payout Ratio.

\section{Pengaruh Growth Opportunity terhadap Dividend Payout Ratio}

Berdasarkan hasil penelitian yang diperoleh mengenai terhadap Dividend Payout Ratio pada Pada Perusahaan Otomotif yang terdaftar di BEI Periode 2013-2017 menyatakan bahwa tidak berpengaruh signifikan. Hal ini dapat dilihat dari nilai sig.0,512 lebih besar dari nilai signifikan 0,05. Berdasarkan hasil yang telah diperoleh maka $\mathrm{H} 0$ diterima. Pada perusahaan otomotif, Asset growth setiap tahunnya mengalami penurunan, hal ini dikarenakan dana sering dialokasikan untuk kegiatan operasional sehingga banyak asset perusahaan ditahan dan tidak berpengaruh terhadap deviden. Semakin tinggi tingkat pertumbuhan perusahaan maka akan semakin besar tingkat kebutuhan dana untuk membiayai total asset perusahaan. Sehingga labanya untuk membiayai ekspansi atau pertumbuhan perusahaan daripada dibayarkan dalam bentuk deviden kepada para pemegang saham. Tanda negative pada koefisien variabel asset growth tidak sesuai dengan asumsi bahwa asset growth akan berpengaruh positif terhadap DPR. Tanda negatif pada penelitian ini dengan alasan bahwa manajer dalam bisnis perusahaan dengan memperhatikan pertumbuhan untuk mengivestasikan pendapatan setelah pajak.

Growth Opportunity perusahaan akan mempengaruhi besarnya dividen yang dibayarkan perusahaan. Hal ini merupakan sinyal tentang pertumbuhan perusahaan dimasa yang akan datang. Besarnya growth opportunity sebuah perusahaan, akan berpengaruh pada jumlah dana yang dibutuhkan untuk investasi dll. Sebaliknya, semakin kecil perumbuhan perusahaan akan berdampak pada pembagian dividend yang akan dibagikan kepada investor. Dalam usahanya pihak manajemen perusahaan pasti akan mencoba untuk memaksimalkan pertumbuhan perusahaan pada tiap periode. Pertumbuhan sebuah perusahaan akan berhubungan langsung dengan kebutuhan pendanaan. Jika perusahaan lebih memfokuskan pada pertumbuhan. Hasil penelitian tersebut sesuai dengan penelitian yang dilakukan oleh (Sari, 2014), (Nadjibah, 2008) yang mengatakan bahwa Growth Opportunity tidak berpengaruh 
signifikan terhadap Dividend Payout Ratio. Berdasarkan hasil penelitian yang dilakukan yang didukung oleh penelitian terdahulu mengenai pengaruh Growth Opportunity terhadap Dividend Payout Ratio maka dapat disimpulkan bahwa ada kesesuaian antara hasil penelitian dengan penelitian terdahulu yakni tidak ada pengaruh signifikan Growth Opportunity terhadap Dividend Payout Ratio.

\section{Pengaruh Return On Assets terhadap Dividend Payout Ratio}

Berdasarkan hasil penelitian yang diperoleh mengenai Return On Assets terhadap Dividend Payout Ratio pada Pada Perusahaan Otomotif yang terdaftar di BEI Tahun 2013-2017 menyatakan bahwa tidak berpengaruh signifikan. Hal ini dapat dilihat dari nilai sig.0,170 lebih besar dari nilai signifikan 0,05. Berdasarkan hasil yang telah diperoleh maka H0 ditolak.

Earning yang tinggi sangat diharapkan oleh perusahaan yang akan mempengaruhi besarnya dividen yang akan dibayarkan oleh perusahaan. Sebaliknya, Kecilnya earning perusahaan akan berdampak pada kinerja perusahan yang kurang baik,sehingga dividen yang akan dibagikan juga akansemakin kecil. Hasil penelitian tersebut sesuai dengan penelitian yang dilakukan oleh (Arseto \& Jufrizen, 2018) ; (Janifairus, Hidayat, \& Husaini, 2013) dan (Wahyuni \& Hafiz, 2018) yang mengatakan bahwa Return On Assets berpengaruh signifikan terhadap Dividend Payout Ratio. Berdasarkan hasil penelitian yang dilakukan yang didukung oleh penelitian terdahulu mengenai pengaruh Growth Opportunity terhadap Dividend Payout Ratio maka dapat disimpulkan bahwa ada kesesuaian antara hasil penelitian dengan penelitian terdahulu yakni tidak ada pengaruh signifikan Growth Opportunity terhadap Dividend Payout Ratio.

\section{Pengaruh Firm Size terhadap Dividend Payout Ratio Melalui Return On Assets}

Hasil penelitian menunjukkan bahwa variabel Firm Size berpengaruh langsung terhadap Dividend Payout Ratio tidak dimediasi oleh Return On Assets. Hal ini dapat dilihat dari nilai koefisien pengaruh tidak langsung lebih kecil dibanding dengan pengaruh langsung dengan melihat (p1 x p5 <p3) yakni -0,1162<0,369. Disini terlihat bahwa Return On Assets tidak dapat memediasi. Pengaruh yang sebenarnya adalah langsung. Ukuran perusahaan langsung dapat langsung memperngaruhi dividen atau capital again tanpa harus mempengaruhi return on assets. Hal ini dikarenakan perusahaan yang memiliki ukuran perusahaan yang besar dapat lebih mudah mendapatkan earning yang lebih besar,sehingga mampu membayar dividen. Banyaknya assets yang dimiliki perusahaan besar dapat menjadi jaminan untuk melakukan pembayaran dividen kepada investor. Hasil penelitian tersebut sesuai dengan penelitian yang dilakukan oleh (Sari, 2014) yang mengatakan bahwa ukuran perusahaan berpengaruh signifikan terhadap Dividend Payout Ratio. Berdasarkan hasil penelitian yang dilakukan yang didukung oleh penelitian terdahulu mengenai pengaruh Firm Size terhadap Dividend Payout Ratio melalui Return On Assets maka dapat disimpulkan bahwa ada kesesuaian antara hasil penelitian dengan penelitian terdahulu yakni Firm Size adanya pengaruh langsung terhadap Dividend Payout Ratio tanpa harus melalui Return On Assets.

\section{Pengaruh Growth Opportunity Terhadap Dividend Payout Ratio Melalui Return on Assets}

Hasil penelitian menunjukkan bahwa Growth Opportunity tidak berpengaruh langsung terhadap Divident Payout Ratio tetapi harus dimediasi oleh Return On Assets. Hal ini dapat dilihat dari nilai koefisien pengaruh tidak langsung lebih kecil dibanding dengan pengaruh langsung dengan melihat (p2 x p5 < p4) yakni 0,0022>-0,093 maka Growht Opportunity tidak berpengaruh langsung terhadap Divident Payout Ratio harus dimediasi oleh Return On Assets. 
Pertumbuhan perusahaan akan mempengaruhi besarnya dividen yang akan dibayarkan kepada pemegang saham, melalui penambahan laba. Dengan penambahan laba dapat mempengaruhi pertumbuhan perusahaan itu sendri. Sehingga dapat disimpulkan bahwa pertumbuhan suatu perusahaan dapat diperngaruhi langsung oleh laba, dengan laba yang besar maka peusahaan dapat membayarkan dividen dengan para pemegang saham. Hasil penelitian tersebut sesuai dengan penelitian yang dilakukan oleh (Sari, 2014) yang mengatakan bahwa Growth Opportunity berpengaruh signifikan terhadap Dividend Payout Ratio. Berdasarkan hasil penelitian yang dilakukan yang didukung oleh penelitian terdahulu mengenai pengaruh Growth Opportunity terhadap Dividend Payout Ratio melalui Return On Assets maka dapat disimpulkan bahwa ada kesesuaian antara hasil penelitian dengan penelitian terdahulu yakni Growth Opportunity tidak berpengaruh langsung terhadap Dividend Payout Ratio tetapi harus melalui Return On Assets.

\section{KESIMPULAN}

Berdasarkan hasil penelitian dan pembahasan yang telah dikemukakan sebelumnya maka dapat diambil kesimpulan dari penelitian mengenai pengaruh Firm Size dan Growth Opportunity terhadap Return On Assets dan Dividend Payout Ratio Pada Perusahaan Sub Sektor Otomotif yang terdaftar di BEI Tahun 2013-2017, maka peneliti menyimpulkan sebagai berikut : Firm Size berpengaruh negatif dan signifikan terhadap Return On Assets Pada Perusahaan Sub Sektor Otomotif di BEI tahun 2013-2017, Growth Opportunity berpengaruh positif dan tidak signifikan terhadap Return On Assets Pada Perusahaan Sub Sektor Otomotif di BEI tahun 2013-2017, Firm Size berpengaruh positif dan signifikan terhadap Dividend Payout Ratio Pada Perusahaan Sub Sektor Otomotif di BEI tahun 2013-2017, Growth Opportunity tidak berpengaruh signifikan terhadap Dividend Payout Ratio Pada Perusahaan Sub Sektor Otomotif di BEI tahun 2013-2017, Return On Assets tidak berpengaruh signifikan terhadap Dividend Payout Ratio Pada Perusahaan Sub Sektor Otomotif di BEI tahun 2013-2017, dan Firm Size bepengaruh terhadap Dividend Payout Ratio tanpa dimediasi oleh Return On Assets Pada Perusahaan Sub Sektor Otomotif di BEI tahun 2013-2017

\section{DAFTAR PUSTAKA}

Al-Saidi, M., \& Al-Shammari, B. (2014). The Relationship between a Firm's Value and Ownership Structure in Kuwait: Simultaneous Analyses Approach. International Business Research, 7(5), 32-48. https://doi.org/10.5539/ibr.v7n5p32

Andinata, W. (2010). Analisis Pengaruh Profitabilitas dan Kebijakan Dividen Terhadap Nilai Perusahaan Manufaktur di Bursa Efek Indonesia. Skripsi. Fakultas Ekonomi Universitas Diponegoro. Semarang.

Arseto, D. D., \& Jufrizen, J. (2018). Pengaruh Return On Asset dan Current Ratio Terhadap Dividen Payout Ratio Dengan Firm Size Sebagai Variabel Moderating. Maneggio: Jurnal Ilmiah Magister Manajemen, 1(1), 15-30.

Atmaja, L. S. (2008). Teori dan Praktik Manajemen Keuangan. Yogyakarta: Andi Offset.

Basir, S., \& Fakhruddin, H. M. (2005). Aksi Korporasi. Jakarta: Salemba Empat.

Brigham, E. F., \& Houston, J. F. (2011). Dasar-dasar Manajemen Keuangan. Jakarta: PT. Salemba Empat.

Gumanti, A. T. (2013). Kebijakan Dividen Teori, Empiris dan Implikasi. Yogyakarta: UPP STIM YKPN Yogyakarta.

Halim, A. (2016). Manajemen Keuangan Sektor Publik. Jakarta: Salemba Empat.

Hani, S. (2015). Teknik Analisa Laporan Keuangan. Medan: UMSU Press.

Hanif, M., \& Bustamam, B. (2017). Pengaruh Debt To Equity Ratio, Return On Asset, Firm 
Size, Dan Earning Pe Share Terhadap Dividend Payout Ratio (Studi pada Perusahaan Manufaktur yang Terdaftar di Bursa Efek Indonesia Tahun 2011-2015). Jurnal Ilmiah Mahasiswa Ekonomi Akuntansi (JIMEKA), 2(1), 73-81.

Harmono. (2015). Manajemen Keuangan Berbasis Balances Scorecard Pendekatan Teori, Kasus, dan Riset Bisnis. Jakarta: Bumi Aksara.

Hasnawati, S. (2005). Dampak Set Peuang Investasi Terhadap Nilai Perusahaan Publik Di Bursa Efek Jakarta. Jurnal Akuntansi Dan Auditing Indonesia, 9(2), 117-126.

Hery. (2018). Analisis Laporan Keuangan Integrated And Comprehensive Edition. Jakarta: PT. Grasindo.

Horne, J. C. Van, \& Wachowicz, J. M. (2009). Prinsip-Prinsip Manajemen Keuangan. Jakarta: Salemba Empat.

Husna, N. (2016). Analisis Firm Size, Growth Opportunity Dan Total Asset Turn Over Terhadap Return On Asset Kasus Pada Perusahaan Food Beverages. E-Jurnal Apresiasi Ekonomi, 4(1), 65-70.

Janifairus, J. B., Hidayat, R., \& Husaini, A. (2013). Pengaruh Return On Asset, Debt To Equity Ratio, Assets Growth, Dan Cash Ratio Terhadap Dividend Payout Ratio (Studi pada Perusahaan Manufaktur Barang Konsumsi yang Listing di Bursa Efek Indonesia Periode 2008-2010). Jurnal Administrasi Bisnis (JAB), 1(1), 161-169.

Juliandi, A., Irfan, \& Manurung, S. (2015). Metodologi Penelitian Bisnis. Medan: UMSU Press.

Kasmir. (2012). Analisa Laporan Keuangan. Jakarta: PT. Raja Grafindo Persada.

Kopong, Y., \& Nurzana, R. (2016). Pengaruh Growth Opportunity Dan Ukuran Perusahaan Terhadap Profitabilitas Dengan Nilai Perusahaan Sebagai Variabel Moderating Pada Perusahaan Manufaktur Yang Terdaftar Di Bursa Efek Indonesia Periode 2011-2014. Jurnal Akuntansi Manajerial, 1(1), 116-133.

Machfoedz, M. (2009). Akuntansi Manajemen. Yogyakarta: BPFE.

Manoppo, H., \& Arie, F. V. (2016). Pengaruh Struktur Modal, Ukuran Perusahaan dan Profitabilitas Terhadap Nilai Perusahaan Otomotif yang Terdaftar di Bursa Efek Indonesia Periode 2011-2014. Jurnal EMBA: Jurnal Riset Ekonomi, Manajemen, Bisnis Dan Akuntansi, 4(2), 485-497.

Munawir, S. (2018). Analisa Laporan Keuangan. Yogykarta: Liberty.

Murhadi, W. R. (2013). Analisis Laporan Keuangan, Proyeksi, dan Valuasi Saham. Jakarta: PT. Salemba Empat.

Nadjibah, N. (2008). Analisis Pengaruh Asset Growth, Size,Cash Ratio Dan Return On Asset Terhadap Dividen Payout Ratio. Thesis Universitas Diponegoro Semarang.

Palupi, I. (2011). Analisis Pengaruh Profitabilitas, Ukuran Perusahaan, Likuiditas, Struktur Aktiva Dan Tingkat Pertumbuhan Perusahaan Terhadap Stuktur Modal Studi Empiris pada Perusahaan Manufaktur yang Terdaftar di Bursa Efek Indonesia Tahun 2007 - 2009. Universitas Sebelas Maret.

Pasadena, R. P. (2013). Pengaruh Likuiditas, Leverage, Profitabilitas Dan Ukuran Perusahaan Terhadap Kebijakan Dividen Pada Perusahaan Manufaktur Yang Terdaftar Di Bursa Efek Indonesia. Skripsi Universitas Islam Negeri Syarif Hidayatullah.

Prasetyo, A. H. (2011). Valuasi Perusahaan. Jakarta: PPM.

Rambe, M. F., Gunawan, A., Julita, Parlidungan, R., Gultom, D. K., \& Wahyuni, S. F. (2015). Manajemen Keuangan. Bandung: Cita Pustaka Media.

Riawan, R. (2019). Debt to Equity Ratio (DER), dan Ukuran Perusahaan yang di Mediasi Oleh Return on Assets (ROA) Terhadap Return Saham. Media Trend: Berkala Kajian Ekonomi \& Studi Pembangunan, 14(1), 136-147. 
Sari, E. S. (2014). Pengaruh Ukuran Perusahaan, Likuiditas, Profitabilitas, Pertumbuhan Perusahaan, Dan Kepemilikan Institusional Terhadap Kebijakan Devidend Payout Ratio (DPR). Ekombis Review: Jurnal Ilmiah Ekonomi Dan Bisnis, 2(2), 231-242. https://doi.org/10.37676/ekombis.v2i2.18

Sartono, A. (2016). Manajemen Keuangan Teori dan Aplikasi (. Yogyakarta: BPFE.

Susanto, S. (1997). Manajemen Aktual Topik-Topik Aktual Manajemen Dalam Riak Perubahan. Jakarta: Grasindo.

Torang, S. (2012). Metode Riset Struktur dan Perilaku Organisasi. Bandung: Alfabeta.

Wahyuni, S. F., \& Hafiz, M. S. (2018). Pengaruh CR, DER dan ROA Terhadap DPR pada Perusahaan Manufaktur di BEI. Jesya (Jurnal Ekonomi \& Ekonomi Syariah), 1(2), 25-42.

Warsono, W. (2003). Manajemen Keuangan Perusahaan. Malang: Bayumedia Publishing. 